\title{
HIV-associated neurocognitive disorders before and during the era of combination antiretroviral therapy: differences in rates, nature, and predictors
}

\author{
Robert K. Heaton • Donald R. Franklin • \\ Ronald J. Ellis • J. Allen McCutchan • \\ Scott L. Letendre • Shannon LeBlanc • \\ Stephanie H. Corkran - Nichole A. Duarte • \\ David B. Clifford • Steven P. Woods • Ann C. Collier • \\ Christina M. Marra • Susan Morgello • \\ Monica Rivera Mindt • Michael J. Taylor • \\ Thomas D. Marcotte • J. Hampton Atkinson • \\ Tanya Wolfson - Benjamin B. Gelman • \\ Justin C. McArthur • David M. Simpson • \\ Ian Abramson - Anthony Gamst • \\ Christine Fennema-Notestine • Terry L. Jernigan • \\ Joseph Wong • Igor Grant • \\ for the CHARTER and HNRC Groups
}

Received: 23 August 2010 /Revised: 07 October 2010 / Accepted: 27 October 2010 / Published online: 21 December 2010

(C) The Author(s) 2010. This article is published with open access at Springerlink.com

\begin{abstract}
Combination antiretroviral therapy (CART) has greatly reduced medical morbidity and mortality with HIV infection, but high rates of HIV-associated neurocognitive disorders (HAND) continue to be reported. Because large HIVinfected $(\mathrm{HIV}+)$ and uninfected $(\mathrm{HIV}-)$ groups have not been studied with similar methods in the pre-CART and CART eras, it is unclear whether CART has changed the prevalence, nature, and clinical correlates of HAND. We used comparable methods
\end{abstract}

R. K. Heaton $(\bowtie) \cdot$ D. R. Franklin $\cdot$ R. J. Ellis $\cdot$

J. A. McCutchan $\cdot$ S. L. Letendre $\cdot$ S. LeBlanc $\cdot$ S. H. Corkran

N. A. Duarte $\cdot$ S. P. Woods $\cdot$ M. J. Taylor $\cdot$ T. D. Marcotte $\cdot$

J. H. Atkinson - T. Wolfson - I. Abramson - A. Gamst •

C. Fennema-Notestine $\cdot$ T. L. Jernigan $\cdot$ J. Wong $\cdot$ I. Grant

University of California,

San Diego, CA, USA

e-mail: rheaton@ucsd.edu

D. R. Franklin

e-mail: dofranklin@ucsd.edu

D. B. Clifford

Washington University,

St. Louis, MO, USA

S. Morgello $\cdot$ M. R. Mindt $\cdot$ D. M. Simpson

Mt. Sinai School of Medicine,

New York, NY, USA of subject screening and assessments to classify neurocognitive impairment (NCI) in large groups of HIV + and HIV participants from the pre-CART era $(1988-1995 ; N=857)$ and CART era (2000-2007; $N=937)$. Impairment rate increased with successive disease stages (CDC stages A, B, and C) in both eras: $25 \%, 42 \%$, and $52 \%$ in pre-CART era and $36 \%$, $40 \%$, and $45 \%$ in CART era. In the medically asymptomatic stage (CDC-A), NCI was significantly more common in the

A. C. Collier · C. M. Marra

University of Washington, Seattle,

Seattle, WA, USA

B. B. Gelman

University of Texas Medical Branch,

Galveston, TX, USA

J. C. McArthur

Johns Hopkins University,

Baltimore, MD, USA 
CART era. Low nadir CD4 predicted NCI in both eras, whereas degree of current immunosuppression, estimated duration of infection, and viral suppression in CSF (on treatment) were related to impairment only pre-CART. Pattern of NCI also differed: pre-CART had more impairment in motor skills, cognitive speed, and verbal fluency, whereas CART era involved more memory (learning) and executive function impairment. High rates of mild NCI persist at all stages of HIV infection, despite improved viral suppression and immune reconstitution with CART. The consistent association of NCI with nadir CD4 across eras suggests that earlier treatment to prevent severe immunosuppression may also help prevent HAND. Clinical trials targeting HAND prevention should specifically examine timing of ART initiation.

Keywords HIV - Combination antiretroviral therapy. HIV dementia

\section{Introduction}

Since the beginning of the HIV/AIDS epidemic, HIVassociated neurocognitive disorders (HAND) have been commonly observed in infected populations (American Academy of Neurology AIDS Task Force 1991; Antinori et al. 2007). These conditions, ranging from subtle neuropsychological impairments to profoundly disabling HIV-associated dementia, are more frequently seen in advanced stages of HIV disease (AIDS) but can occur even in individuals having medically asymptomatic HIV infection (CDC 1993 Stage A; Grant et al. 1987; Heaton et al. 1995; White et al. 1995). Moreover, HAND confers an increased risk for early mortality, independent of medical predictors (Ellis et al. 1997a; Mayeux et al. 1993), and often interferes significantly with cognitively demanding activities of daily living (e.g., employment, medication management, driving; Heaton et al. 2004b; Hinkin et al. 2004; Marcotte et al. 1999, 2004).

The availability of combination antiretroviral therapy (CART) since 1996 has successfully controlled HIV viremia and improved immune function in many treated, HIV-infected $(\mathrm{HIV}+)$ patients, leading to dramatic improvements in medical morbidity and life expectancy. Clear improvement in neurological outcomes in the era of CART also has been achieved, with a significant drop in the rate of frank HIV-associated dementia (Dore et al. 2003; Robertson et al. 2007; Sacktor et al. 2002). Pre-CART prevalence estimates were approximately $16 \%$ in AIDS cases (McArthur et al. 1993), whereas more recent estimates are less than 5\% (Heaton et al. 2010). Further benefits of CART on the broader spectrum of HAND have been suggested by studies of neurocognitive change in $\mathrm{HIV}+$ groups initiating CART regimens. A recent review of 15 such studies indicated that 11 found some improvement in neurocognitive test performance after an average of
6 months on CART, although most studies had relatively small sample sizes and did not control for practice effects on repeated testing (Joska et al. 2010).

Unfortunately, however, beneficial effects of CART on neurologic manifestations of HIV infection, especially HAND, have been less than complete (McArthur and Brew. 2010). Neurocognitive responses to CART have been varied across individuals, and studies of HAND in treated patients have documented high persisting rates of mild-to-moderate neurocognitive impairment (NCI). For example, Robertson et al. (2007) assembled data on 1,160 HIV + patients involved in 14 different clinical trials involving CART. All participants completed a brief neurocognitive battery at least 20 weeks after randomization to treatment; 921 participants completed a follow-up exam 48 weeks later. Prevalence of NCI was $39 \%$ at baseline. Although $44 \%$ of those with NCI at baseline appeared to show CART-related improvement at follow-up (performed within the "normal" range, but with no apparent correction for practice effect), $21 \%$ of participants who were $\mathrm{NC}$ normal at baseline experienced incident impairment at follow-up. As a result, the total rate of NCI at follow-up was not very different from that at baseline (34\% vs. $39 \%$ ). In another study of persisting NCI on CART, Tozzi et al. (2007) followed 94 treated patients for a mean of 5 years (multiple assessments). All had NCI at baseline, and $63 \%$ showed persisting impairment; however, this could be an underestimate because, again, it is unclear whether or not they controlled for practice effects on the neurocognitive tests. A third recent study reported HAND in $69 \%$ of 200 $\mathrm{HIV}+$ patients who had maintained good virologic response (undetectable HIV RNA in plasma on CART) over a median of 48 months (Simioni et al. 2010).

Causes of continuing high rates of HAND in the CART era are uncertain, but multiple non-exclusive possibilities have been suggested: irreversible brain injury prior to initiating CART, incomplete viral suppression in the central nervous system (CNS) due to poor CNS penetration of some commonly used antiretroviral drugs and/or presence of drug-resistant viral strains, the possibility that even very low levels of viral replication in the CNS could result in neural injury or dysfunction due to prolonged exposure to inflammatory responses and neurotoxic viral proteins, possible neurotoxicity of antiretroviral therapy (ART) drugs, and exposure to other conditions that may affect cognition in long-term survivors, such as increased rates of metabolic abnormalities and associated vascular pathology or increased B-amyloid deposition in the brain.

In sum, although the most severe form of HAND, HIVassociated dementia, appears to be much less common in the era of CART, questions remain about any long-term benefit of CART with respect to milder forms of HAND. These abnormalities remain highly prevalent, and it is unclear whether their nature, pathophysiological mecha- 
nisms, and clinical predictors have changed. Optimal comparison of HAND across time requires consistent definitions and testing, substantial representative cohorts, and sufficient knowledge of context including non-HIV (comorbid) conditions to achieve informative analysis.

This study compares baseline neuropsychological (NP) and neuromedical findings of two large cohorts of HIV + and HIV - participants who were recruited and assessed as part of a long-range program of research coordinated by the UCSD HIV Neurobehavioral Research Center (HNRC). Through collaborations with multiple institutions (listed in the acknowledgements), we performed comparable neuromedical and neurocognitive examinations on 857 participants from the pre-CART era and 936 from the CART era. Participants were recruited through advertisements and outreach to various communities and health care providers. It should be noted that these were not referral populations (i.e., not weighted to persons suspected or known to have neurologic disease). An almost identical NP test battery covering seven ability domains was used to classify HAND according to recently published international guidelines (Antinori et al. 2007). In order to provide comparable exclusions and minimize the effects of comorbid conditions on NP results, potential participants in both cohorts were carefully screened and excluded if they had any history of significant non-HIV-related risks for cognitive impairment. Rates of HAND were compared across eras in subgroups that were stratified by HIV serostatus and clinical stage of infection (HIV - controls vs. CDC 1993 stages A, B, and C). (Although the $2008 \mathrm{CDC}$ classification system has deemphasized the distinction between historic, asymptomatic, and mildly symptomatic HIV disease, we included all three stages in the current analyses to provide links with earlier studies of HAND and because most of our participants had been classified before the new guidelines were published (Centers for Disease Control 2008).) Immunological and virological predictors of HAND also were assessed and compared across eras. Finally, to explore possible qualitative differences in neurobehavioral outcomes, we compared severity and patterns of impairment across the seven ability domains for $\mathrm{HIV}+$ participants from the two eras.

\section{Results}

Demographic, psychiatric, and neuropsychological comparisons of treatment era subgroups

Table 1 displays the demographic characteristics, psychiatric history, and NP status of the treatment era participants, stratified by HIV serostatus and CDC-1993 disease stage. Consistent with CDC HIV/AIDS surveillance reports, demographic differences reflect changes in the US HIV/
AIDS epidemic over time, i.e., the infected population is somewhat older and contains higher proportions of females and ethnic minorities, as well as higher proportions of people reporting any history of injection drug use or who reported heterosexual contact as their only infection risk (Centers for Disease Control and Prevention 1992, 1994, 1996, 2000, 2004, 2008). CART era patients also tended to have slightly lower education levels than pre-CART era participants. Because classification of NCI was done using demographically corrected test norms, the demographic differences between treatment era groups did not bias the NCI prevalence estimates across time; i.e., there are no meaningful demographic differences between participant groups with and without $\mathrm{NCI}$ in either treatment era cohort (see Table 3).

As is typical of HIV + groups and HIV - controls with similar risk backgrounds, fairly high lifetime prevalence rates of major depressive disorder and substance use disorders are observed in both eras; however, fewer individuals met the criteria for current diagnoses at the time of testing (i.e., met diagnostic criteria for a DSMdefined disorder within the last 30 days). Higher rates of lifetime substance use disorders were seen in the CART era groups (Table 1), but these conditions were not related to $\mathrm{NCI}$ in the HIV + groups from that era (Table 3).

In both treatment eras, increased rates of NCI are seen when comparing seronegative controls and subgroups at successive CDC stages of (historic) HIV disease, in a stairstep pattern (Fig. 1). Although there are no treatment era differences in NCI rates among seronegative controls or infected individuals in $\mathrm{CDC}$ stages $\mathrm{B}$ and $\mathrm{C}$, impairment rate among CART era participants in CDC stage $\mathrm{A}$ is higher than that in their pre-CART counterparts $(36.2 \%$ vs. $25.2 \%$, $p=0.001$ ). While in the pre-CART era rates of moderate to severe impairment (consistent with HIV-associated dementia) increased in subgroups with successively more advanced CDC stages of HIV disease $(4 \%, 12 \%$, and $17 \%$ for CDC stages $\mathrm{A}, \mathrm{B}$, and $\mathrm{C}$ ), this pattern was not seen in the CART era subgroups ( $7-8 \%$ for all disease stages).

Characteristics of HIV infection and treatment in pre-CART and CART era HIV + participants

Table 2 shows HIV disease data for infected subgroups. The participants in both treatment eras who had more advanced CDC stage reported longer durations of known infection, but there was a significantly larger (threefold) difference in estimated disease duration between treatment era subgroups at each disease stage. Irrespective of disease stage, the CART era participants had been infected longer, reflecting improved survival. Patterns of nadir and current immunosuppression were also significantly different for the two treatment era cohorts: the CART era participants tended 
Table 1 Pre CART and CART group characteristics by HIV serostatus and CDC stage

\begin{tabular}{|c|c|c|c|c|c|}
\hline & $\begin{array}{l}\text { HIV- Controls }{ }^{\mathrm{a}} \\
\text { (Group 0) }\end{array}$ & $\mathrm{CDC}-\mathrm{A}^{\mathrm{a}}$ & $\mathrm{CDC}-\mathrm{B}^{\mathrm{a}}$ & CDC-C ${ }^{\mathrm{a}}$ & $\begin{array}{l}\text { Within Era Group } \\
\text { Differences }{ }^{b}\end{array}$ \\
\hline \multicolumn{6}{|l|}{$\mathrm{N}$} \\
\hline Pre & 179 & 412 & 181 & 85 & \\
\hline CART & 94 & 337 & 216 & 290 & \\
\hline \multicolumn{6}{|l|}{ Age } \\
\hline Pre & $33.1(7.8)$ & $31.6(7.5)$ & $33.7(6.4)$ & $37.4(6.9)$ & $\mathrm{A}<0, \mathrm{~B}<\mathrm{C}$ \\
\hline CART & $34.8(11.8)$ & $40.8(10.2)^{* * *}$ & $43.4(7.4) * * *$ & $44.3(7.7) * * *$ & $0<\mathrm{A}<\mathrm{B}, \mathrm{C}$ \\
\hline \multicolumn{6}{|l|}{ Education } \\
\hline Pre & $14.0(2.5)$ & $13.4(2.1)$ & $13.2(2.2)$ & $13.8(2.0)$ & $0>\mathrm{A}, \mathrm{B} ; \mathrm{B}<\mathrm{C}$ \\
\hline CART & $13.0(2.2) * * *$ & $13.3(2.5)$ & $12.7(2.4)^{*}$ & $12.9(2.5)^{* *}$ & $\mathrm{~A}>\mathrm{B}$ \\
\hline \multicolumn{6}{|l|}{$\%$ Male } \\
\hline Pre & $78.8 \%$ & $90.5 \%$ & $85.6 \%$ & $88.2 \%$ & $0<\mathrm{A}$ \\
\hline CART & $58.5 \% * * *$ & $81.6 \%$ & $72.2 \% * *$ & $81.4 \%$ & $0<\mathrm{B}<\mathrm{A}, \mathrm{C}$ \\
\hline \multicolumn{6}{|c|}{$\%$ Caucasian } \\
\hline Pre & $67.6 \%$ & $65.0 \%$ & $71.8 \%$ & $69.4 \%$ & \\
\hline CART & $64.9 \%$ & $43.6 \% * * *$ & $45.4 \% * * *$ & $42.8 \% * * *$ & $0>\mathrm{A}, \mathrm{B}, \mathrm{C}$ \\
\hline \multicolumn{6}{|c|}{ HIV infection risk - MSM } \\
\hline Pre & $49.4 \%$ & $71.3 \%$ & $70.2 \%$ & $77.4 \%$ & $0<\mathrm{A}, \mathrm{B}, \mathrm{C}$ \\
\hline CART & $32.2 \% * *$ & $47.3 \% * * *$ & $41.0 \% * * *$ & $39.2 \% * * *$ & $\mathrm{~A}>0, \mathrm{C}$ \\
\hline \multicolumn{6}{|c|}{ HIV infection risk - any IDU } \\
\hline Pre & $2.3 \%$ & $3.9 \%$ & $6.1 \%$ & $3.6 \%$ & \\
\hline CART & $1.1 \%$ & $12.2 \% * * *$ & $19.5 \% * * *$ & $23.9 \% * * *$ & $0<\mathrm{A}<\mathrm{B}<\mathrm{C}$ \\
\hline \multicolumn{6}{|c|}{ HIV infection risk - Heterosexual } \\
\hline Pre & $43.8 \%$ & $25.8 \%$ & $23.8 \%$ & $19.0 \%$ & $0>\mathrm{A}, \mathrm{B}, \mathrm{C}$ \\
\hline CART & $66.7 \% * *$ & $40.4 \% * * *$ & $39.5 \% * *$ & $36.9 \% * *$ & $0>\mathrm{A}, \mathrm{B}, \mathrm{C}$ \\
\hline \multicolumn{6}{|c|}{ Alcohol Disorder } \\
\hline \multicolumn{6}{|c|}{ Lifetime } \\
\hline Pre & $32.8 \%$ & $32.9 \%$ & $44.5 \%$ & $46.7 \%$ & $0<\mathrm{B} ; \mathrm{A}<\mathrm{B}, \mathrm{C}$ \\
\hline CART & $19.1 \% *$ & $50.3 \% * * *$ & $54.4 \%$ & $60.8 \% *$ & $0<\mathrm{A}<\mathrm{C}$ \\
\hline \multicolumn{6}{|l|}{ Current } \\
\hline Pre & $5.4 \%$ & $4.5 \%$ & $8.8 \%$ & $6.2 \%$ & \\
\hline CART & $2.1 \%$ & $1.8 \% *$ & $2.3 \% * *$ & $1.0 \% * *$ & \\
\hline \multicolumn{6}{|c|}{ Other Substance Use Disorder } \\
\hline \multicolumn{6}{|c|}{ Lifetime } \\
\hline Pre & $26.2 \%$ & $22.7 \%$ & $33.1 \%$ & $40.6 \%$ & $0<\mathrm{C} ; \mathrm{A}<\mathrm{B}<\mathrm{C}$ \\
\hline CART & $19.1 \%$ & $52.1 \% * * *$ & $65.1 \% * * *$ & $62.5 \% * *$ & $0<\mathrm{A}<\mathrm{B}, \mathrm{C}$ \\
\hline \multicolumn{6}{|l|}{ Current } \\
\hline Pre & $2.7 \%$ & $3.2 \%$ & $4.7 \%$ & $6.2 \%$ & \\
\hline CART & $5.3 \%$ & $2.7 \%$ & 1.4 & $0.7 \% *$ & $0>\mathrm{B}, \mathrm{C}$ \\
\hline \multicolumn{6}{|c|}{ Major Depressive Disorder } \\
\hline \multicolumn{6}{|c|}{ Lifetime } \\
\hline Pre & $52.5 \%$ & $42.2 \%$ & $57.2 \%$ & $57.4 \%$ & $\mathrm{~A}<0, \mathrm{~B}, \mathrm{C}$ \\
\hline CART & $23.4 \% * * *$ & $44.0 \%$ & $54.4 \%$ & $45.1 \%$ & $0<\mathrm{A}, \mathrm{C}, \mathrm{B}$ \\
\hline \multicolumn{6}{|l|}{ Current } \\
\hline Pre & $6.7 \%$ & $11.7 \%$ & $23.6 \%$ & $21.9 \%$ & $0, \mathrm{~A}<\mathrm{B}, \mathrm{C}$ \\
\hline CART & $6.4 \%$ & $11.0 \%$ & $19.5 \%$ & $11.8 \% *$ & $0, \mathrm{~A}, \mathrm{C}<\mathrm{B}$ \\
\hline \multicolumn{6}{|c|}{$\begin{array}{l}\text { Beck Depression } \\
\text { Inventory Total }\end{array}$} \\
\hline Pre & $5.9(7.0)$ & $7.7(7.9)$ & $11.9(8.9)$ & $11.7(7.9)$ & $0<\mathrm{A}<\mathrm{B}, \mathrm{C}$ \\
\hline CART & $5.3(6.6)$ & $10.2(9.2)$ & $14.7(10.5)$ & $13.0(9.9)$ & $0<\mathrm{A}<\mathrm{B}, \mathrm{C}$ \\
\hline
\end{tabular}


Table 1 (continued)

\begin{tabular}{|c|c|c|c|c|c|}
\hline & $\begin{array}{l}\text { HIV- Controls } \\
\text { (Group 0) }\end{array}$ & CDC-A ${ }^{a}$ & $\mathrm{CDC}-\mathrm{B}^{\mathrm{a}}$ & $\mathrm{CDC}-\mathrm{C}^{\mathrm{a}}$ & $\begin{array}{l}\text { Within Era Group } \\
\text { Differences }{ }^{\text {b }}\end{array}$ \\
\hline \multicolumn{6}{|c|}{ \% Employed } \\
\hline Pre & $69.6 \%$ & $80.6 \%$ & $53.57 \%$ & $29.8 \%$ & $\mathrm{~A}>0>\mathrm{B}>\mathrm{C}$ \\
\hline CART & $60.2 \%$ & $44.5 \% * * *$ & $27.8 \% * * *$ & $23.4 \%$ & $0>\mathrm{A}>\mathrm{B}, \mathrm{C}$ \\
\hline \multicolumn{6}{|c|}{ PAOFI Cognitive Symptoms } \\
\hline Pre & $2.5(3.1)$ & $2.9(4.8)$ & $6.0(7.0)$ & $4.3(6.1)$ & $\mathrm{B}>\mathrm{C}>\mathrm{A}, 0$ \\
\hline CART & $2.5(4.2)$ & $4.2(6.1)$ & $5.1(6.0)$ & $5.4(6.7)$ & $0<\mathrm{A}, \mathrm{B}, \mathrm{C} ; \mathrm{A}<\mathrm{C}$ \\
\hline \multicolumn{6}{|c|}{$\%$ Neurocognitively Impaired } \\
\hline Pre & $19.0 \%$ & $25.2 \%$ & $42.0 \%$ & $51.8 \%$ & $0, \mathrm{~A}<\mathrm{B}, \mathrm{C}$ \\
\hline CART & $16.0 \%$ & $36.2 \% * *$ & $40.3 \%$ & $44.8 \%$ & $0<\mathrm{A}, \mathrm{B}, \mathrm{C} ; \mathrm{A}<\mathrm{C}$ \\
\hline \multicolumn{6}{|c|}{$\%$ Moderately - Severely NC Impaired } \\
\hline Pre & $1.7 \%$ & $3.6 \%$ & $12.1 \%$ & $16.5 \%$ & $0, \mathrm{~A}<\mathrm{B}, \mathrm{C}$ \\
\hline CART & $2.1 \%$ & $7.1 \% *$ & $7.8 \%$ & $6.9 \% * *$ & \\
\hline
\end{tabular}

PAOFI=Patient's Assessment of Own Functioning Inventory

$* \mathrm{p}<.05 ; * * \mathrm{p}<.01 ; * * \mathrm{p}<.001$ for comparisons of pre-CART and CART era subgroups

${ }^{a}$ Asterisks in these columns reflect significant treatment era differences between pre-CART and CART era subgroups defined by HIV serostatus and CDC HIV disease stage, using chi square or t-tests, as appropriate.

b Differences in this column $(<$ or $>$ ) reflect significant results of "within treatment era" comparisons of subgroups defined by HIV serostatus and CDC HIV disease stage, using chi-square or Students t-tests as appropriate.

to have much lower nadir CD4 cell counts, especially in participants with less advanced clinical disease histories (i.e., CDC stages A and B). On average, the CART era participants in all three disease stages were more likely to be receiving ART and had much greater immune improvement (difference between nadir and current CD4). Also, consistent with expected differences in treatment effects, being on ART was associated with a significantly higher (twofold) likelihood of achieving plasma viral suppression in the CART era (undetectable viral RNA), but not in the pre-CART era. Similar patterns are seen for suppression of HIV in cerebrospinal fluid (CSF) (see Table 2).
Pre-CART vs. CART era associations between NCI and demographics, psychiatric histories, HIV disease and treatment characteristics, and everyday functioning

Table 3 addresses possible treatment era differences in associations between NCI and other variables of interest. Impaired participants were very slightly older (not a clinically significant difference), and no other demographic characteristics (education, gender, or ethnicity), were associated with impairment. NCI is associated with unemployment, reports of cognitive difficulties in everyday life (Patient's Assessment of Own Functioning Inventory), and
Fig. 1 Neurocognitive impairment in the pre-CART and CART eras by serostatus and CDC stage, ${ }^{* * *} p=0.001$

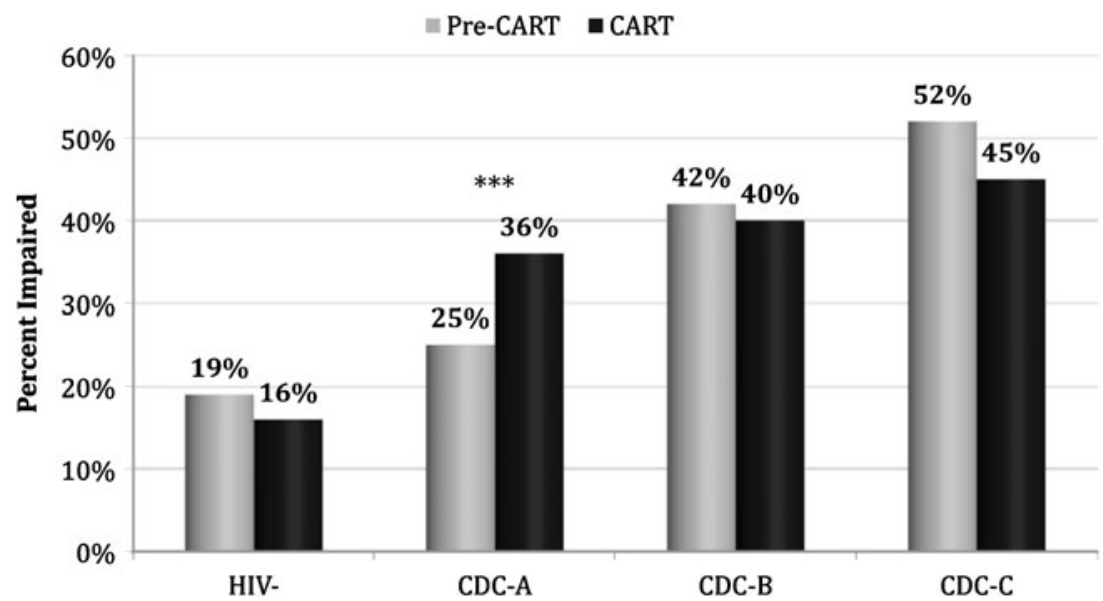


Table 2 Disease and treatment characteristics of pre-CART and CART HIV + groups

\begin{tabular}{|c|c|c|c|c|}
\hline & $\mathrm{CDC}-\mathrm{A}^{\mathrm{a}}$ & CDC-B ${ }^{a}$ & $\mathrm{CDC}_{-} \mathrm{C}^{\mathrm{a}}$ & $\begin{array}{l}\text { Within Era Group } \\
\text { Differences }{ }^{\text {b }}\end{array}$ \\
\hline \multicolumn{5}{|l|}{$\mathrm{N}$} \\
\hline Pre & 412 & 181 & 85 & \\
\hline CART & 337 & 216 & 290 & \\
\hline \multicolumn{5}{|c|}{ Estimated Infection Duration (years) } \\
\hline Pre & $2.3(2.5)$ & $3.5(2.9)$ & $3.5(3.4)$ & $\mathrm{A}<\mathrm{B}, \mathrm{C}$ \\
\hline CART & $7.1(6.0)^{* * *}$ & $10.3(6.0)^{* * *}$ & $11.9(6.0)^{* * *}$ & $\mathrm{~A}<\mathrm{B}<\mathrm{C}$ \\
\hline \multicolumn{5}{|c|}{ Nadir CD4 (cells $/ \mathrm{ml})^{\mathrm{c}}$} \\
\hline Pre & $455[324-600]$ & $273[159-430]$ & $40[12-155]$ & $\mathrm{A}>\mathrm{B}>\mathrm{C}$ \\
\hline CART & $295[200-400]^{* * *}$ & $162[69-291]^{* *}$ & $50[10-153]$ & $\mathrm{A}>\mathrm{B}>\mathrm{C}$ \\
\hline \multicolumn{5}{|c|}{$\%$ Nadir CD4 < $200(\text { cells } / \mathrm{ml})^{\mathrm{c}}$} \\
\hline Pre & $6.8 \%$ & $32.0 \%$ & $81.2 \%$ & $\mathrm{~A}<\mathrm{B}<\mathrm{C}$ \\
\hline CART & $24.6 \% * * *$ & $59.7 \% * *$ & $84.5 \%$ & $\mathrm{~A}<\mathrm{B}<\mathrm{C}$ \\
\hline \multicolumn{5}{|c|}{ Current CD4 (cells $/ \mathrm{ml})^{\mathrm{c}}$} \\
\hline Pre & $485[344-660]$ & 304 [186-438] & $40[12-161]$ & $\mathrm{A}>\mathrm{B}>\mathrm{C}$ \\
\hline CART & 496 [343-697] & $437[251-616]^{* * *}$ & $346[204-552]^{* * *}$ & $\mathrm{~A}>\mathrm{B}>\mathrm{C}$ \\
\hline \multicolumn{5}{|c|}{$\%$ CurrentCD4 $<200(\text { cells } / \mathrm{ml})^{\mathrm{c}}$} \\
\hline Pre & $6.3 \%$ & $28.6 \%$ & $80.0 \%$ & $\mathrm{~A}<\mathrm{B}<\mathrm{C}$ \\
\hline CART & $7.8 \%$ & $17.7 \% * *$ & $24.2 \% * * *$ & $\mathrm{~A}, \mathrm{~B}, \mathrm{C}$ \\
\hline \multicolumn{5}{|c|}{ CD4 Increase (current - nadir) ${ }^{\mathrm{c}}$} \\
\hline Pre & $36[0-130]$ & $0[0-45]$ & $0[0-5]$ & $\mathrm{A}>\mathrm{B}, \mathrm{C}$ \\
\hline CART & $158[41-317]^{* * *}$ & $234[80-414]^{* * *}$ & $249[110-410]^{* * *}$ & $\begin{array}{c}\mathrm{A}<\mathrm{B} \\
\mathrm{C}\end{array}$ \\
\hline \multicolumn{5}{|c|}{$\%$ on ART } \\
\hline Pre & $37.9 \%$ & $59.1 \%$ & $67.1 \%$ & $\mathrm{~A}<\mathrm{B}, \mathrm{C}$ \\
\hline CART & $52.2 \% * * *$ & $74.1 \% * *$ & $87.2 \% * * *$ & $\mathrm{~A}<\mathrm{B}<\mathrm{C}$ \\
\hline \multicolumn{5}{|c|}{ \# of ARVs (on treatment only) } \\
\hline Pre & $1.0(0.2)$ & $1.2(0.41)$ & $1.1(0.40)$ & $\mathrm{A}<\mathrm{B}, \mathrm{C}$ \\
\hline CART & $3.5(0.75)^{* * *}$ & $3.7(0.87)^{* * *}$ & $3.8(0.98)^{* * *}$ & $\mathrm{~A}<\mathrm{C}$ \\
\hline \multicolumn{5}{|c|}{ \% Detectable HIV RNA - Plasma (on ART) } \\
\hline Pre & $95.0 \%$ & $98.0 \%$ & $96.5 \%$ & \\
\hline CART & $42.5 \% * * *$ & $43.3 \% * * *$ & $48.4 \% * * *$ & \\
\hline \multicolumn{5}{|c|}{$\%$ Detectable HIV RNA - CSF (on ART) } \\
\hline Pre & $47.8 \%$ & $65.5 \%$ & $37.5 \%$ & $\mathrm{~B}>\mathrm{C}$ \\
\hline CART & $14.0 \% * * *$ & $19.0 \% * * *$ & $18.6 \% *$ & \\
\hline
\end{tabular}

$\mathrm{ART}=$ antiretroviral therapy; $\mathrm{ARVs}=$ antiretroviral drugs

$* \mathrm{p}<.05 ; * * \mathrm{p}<.01 ; * * * \mathrm{p}<.001$ for comparisons of pre-CART and CART era subgroups

${ }^{a}$ Asterisks in these columns reflect significant treatment era differences between pre-CART and CART era subgroups defined by HIV serostatus and CDC HIV disease stage, using chi square or t-tests, as appropriate.

b Differences in this column $(<$ or $>$ ) reflect significant results of "within treatment era" comparisons of subgroups defined by HIV serostatus and CDC HIV disease stage, using chi-square or Students t-tests as appropriate.

c Cell counts shown as median (interquartile range)

current depressive symptoms (Beck Depression Inventory) in both eras.

Associations between NCI and infection risk categories and psychiatric history differed between the two treatment era cohorts (Table 3 ). In the pre-CART cohort, a history of lifetime (but not current) substance use disorders was associated with NCI. This association was not found in the CART era cohort even though those participants had much higher rates of (mostly remote) alcohol and other substance use disorders. Indeed, those with NCI in the CART era were less likely to have prior substance use disorders (54.9\% vs. $61.7 \%$ for NC normal; chi-squared= 3.92, $p<0.05)$.

Turning to disease and treatment-related correlates of NCI, low nadir CD4 counts increased risk for NCI in both treatment eras. In contrast, impairment was also related to 
Table 3 Difference between neurocognitively impaired and normal HIV+ subgroups by treatment era

\begin{tabular}{|c|c|c|c|c|c|c|}
\hline & \multicolumn{2}{|l|}{ Pre CART era } & & \multicolumn{2}{|l|}{ CART era } & \\
\hline & NP Normal & NP Impaired & & NP Normal & NP Impaired & \\
\hline $\mathrm{N}$ & 454 & 224 & & 504 & 339 & \\
\hline Age & $32.4(7.4)$ & $33.9(7.3)$ & * & $42.2(8.9)$ & $43.3(8.8)$ & \\
\hline Education & $13.4(2.1)$ & $13.4(2.1)$ & & $12.9(2.5)$ & $13.1(2.5)$ & \\
\hline$\%$ Male & $89.8 \%$ & $87.0 \%$ & & $77.0 \%$ & $80.6 \%$ & \\
\hline$\%$ Caucasian & $68.5 \%$ & $65.2 \%$ & & $43.2 \%$ & $44.5 \%$ & \\
\hline \% Employed & $75.0 \%$ & $52.5 \%$ & $* * *$ & $35.7 \%$ & $28.9 \%$ & * \\
\hline Cognitive Symptoms (PAOFI) & $2.8(4.4)$ & $6.5(7.5)$ & $* * *$ & $4.1(5.5)$ & $6.0(7.1)$ & $* * *$ \\
\hline Beck Depression Inventory Total & $8.0(7.5)$ & $12.3(9.5)$ & $* * *$ & $11.7(9.7)$ & $13.2(10.2)$ & $*$ \\
\hline \multicolumn{7}{|l|}{ HIV Infection Risk } \\
\hline MSM only & $72.6 \%$ & $70.0 \%$ & & $46.6 \%$ & $37.5 \%$ & $*$ \\
\hline IVDU & $3.1 \%$ & $5.5 \%$ & & $18.4 \%$ & $17.8 \%$ & \\
\hline Heterosexual only & $24.3 \%$ & $24.5 \%$ & & $35.0 \%$ & $44.7 \%$ & $* *$ \\
\hline \multicolumn{7}{|l|}{ Psychiatric Diagnoses (current/lifetime) } \\
\hline \multicolumn{7}{|l|}{ Lifetime } \\
\hline Alcohol & $31.5 \%$ & $50.9 \%$ & $* * *$ & $57.0 \%$ & $51.9 \%$ & \\
\hline Other Substance & $24.8 \%$ & $33.1 \%$ & * & $61.7 \%$ & $54.9 \%$ & * \\
\hline MDD & $40.6 \%$ & $50.6 \%$ & * & $48.0 \%$ & $45.7 \%$ & \\
\hline \multicolumn{7}{|l|}{ Current } \\
\hline Alcohol & $5.8 \%$ & $5.6 \%$ & & $2.2 \%$ & $0.9 \%$ & \\
\hline Other Substance & $2.9 \%$ & $5.6 \%$ & & $2.0 \%$ & $1.2 \%$ & \\
\hline MDD & $13.6 \%$ & $20.8 \%$ & * & $12.9 \%$ & $14.2 \%$ & \\
\hline Duration of Infection (years) & $2.5(2.6)$ & $3.4(3.0)$ & $* * *$ & $9.8(6.3)$ & $9.3(6.3)$ & \\
\hline Nadir $C D 4^{\mathrm{a}}$ & $390[236-550]$ & $321[162-514]$ & $* *$ & $198[62-338]$ & $166[44-290]$ & $* *$ \\
\hline$\%$ Nadir CD $4<200$ & $18.7 \%$ & $30.0 \%$ & $*$ & $50.6 \%$ & $59.6 \%$ & $* *$ \\
\hline$\%$ ART & $45.6 \%$ & $50.4 \%$ & & $66.1 \%$ & $75.5 \%$ & $* *$ \\
\hline CDC-A & $39.0 \%$ & $34.6 \%$ & & $50.2 \%$ & $55.7 \%$ & \\
\hline CDC-B & $55.2 \%$ & $64.5 \%$ & & $70.0 \%$ & $81.6 \%$ & * \\
\hline CDC-C & $70.7 \%$ & $63.6 \%$ & & $85.0 \%$ & $90.0 \%$ & \\
\hline \# of ARVs (on ART) & $1.3(.33)$ & $1.1(.35)$ & & $3.6(.90)$ & $3.7(.89)$ & \\
\hline Current $\mathrm{CD} 4^{\mathrm{a}}$ & 408 [252-572] & 350 [182-552] & * & $442[276-608]$ & 425 [253-632] & \\
\hline Current CD4 (on ART) ${ }^{\mathrm{a}}$ & 318 [191-427] & 268 [119-437] & & $438[263-625]$ & 408 [246-629] & \\
\hline$\%$ Current $\mathrm{CD} 4<200$ & $17.8 \%$ & $27.7 \%$ & $* *$ & $14.2 \%$ & $18.6 \%$ & \\
\hline$\%$ Current $<200$ (on ART) & $26.7 \%$ & $37.8 \%$ & & $15.1 \%$ & $19.6 \%$ & \\
\hline CD4 Increase (current - nadir) ${ }^{\mathrm{a}}$ & $4[0-94]$ & $12[0-101]$ & & $199[64-351]$ & $229[78-388]$ & \\
\hline CD4 Recovery (on ART) ${ }^{\mathrm{a}}$ & $0[0-62]$ & $21[0-120]$ & & $269[137-443]$ & $267[134-439]$ & \\
\hline$\%$ Detectable HIV RNA - Plasma (on ART) & $95.3 \%(\mathrm{n}=85)$ & $98.2 \%(n=55)$ & & $44.1 \%(n=329)$ & $46.8 \%(n=254)$ & \\
\hline \% Detectable HIV RNA - CSF (on ART) & $46.2 \%(n=91)$ & $63.6 \%(n=55)$ & * & $17.6 \%(n=255)$ & $16.8 \%(\mathrm{n}=190)$ & \\
\hline
\end{tabular}

PAOFI = Patient's Assessment of Own Functioning; MSM = Men who have sex with men; IVDU = Intravenous drug user; MDD = Major Depressive Disorder

$* \mathrm{p}<.05 ; * * \mathrm{p}<.01 ; * * * \mathrm{p}<.001$

Significant differences are between NCI and NC-normal subgroups within treatment eras, as determined by chi-square or t-test, as appropriate.

a Cell counts shown as median (interquartile range)

duration of infection and current degree of immunosuppression only in the pre-CART era. Also, although Table 1 indicates that higher rates of NCI were seen with more symptomatic disease histories (CDC-1993 stages A vs. B vs. C) in both treatment eras, associations of $\mathrm{NC}$ outcomes with disease history are significant and independent of nadir CD4 only pre-CART; i.e., when nadir CD4 is covaried in the analyses, more symptomatic CDC-1993 
disease stages were associated with worse NP Global Ratings in the pre-CART $(F(d f=3,669)=15.8, p<0.0001$; $\mathrm{A}<\mathrm{B}<\mathrm{C})$ but not in the CART-era cohort $(F(d f=3,843)=$ 1.8, $p=0.14$ ). Antiretroviral (ARV) treatment itself was associated with NCI only in the CART era, but this "effect" is statistically significant only for CDC stage B. Immune improvement on treatment (current CD4 minus nadir CD4) was minimal in the pre-CART era and substantial CART era, but in neither era was this related to NCI. Treatment reduced HIV viremia only in the CART era, but successful viral suppression in plasma did not relate to lower risk of $\mathrm{NCI}$ in either era. Finally, in treated individuals, NCI was associated with failure to achieve viral suppression in the CSF in the pre-CART era, but not in the CART era.

Treatment era differences in pattern of impairment across ability domains

Figure 2 displays the rates of impairment across the seven major ability domains for the participants with $\mathrm{NCI}$ in each treatment era. NCI in the pre-CART era was more often characterized by deficits in motor speed/dexterity, speed of information processing, and verbal fluency, whereas the learning and executive function domains were more affected in the CART era.

\section{Discussion}

In one of the few prior direct comparisons of HAND in the pre-CART $(n=272)$ and CART $(n=251)$ eras, Sacktor et al. (2002) found no significant difference in prevalence rates of $\mathrm{NCI}$ in large but demographically very different cohorts of HIV + patients who were comparably screened for comorbidities. However, the high rates of observed impairment $(74.3 \%$ vs. $76 \%)$ may have occurred because both cohorts were specifically selected for being at high risk for
NCI (low CD4 cell counts and/or clinical evidence of impairment).

A second previous direct comparison of pre-CART $(n=$ $51)$ and CART $(n=90)$ era groups was conducted by Cysique et al. (2004) in Australia. These investigators studied demographically similar HIV + groups in the same university clinic, in which participants all had AIDS (i.e., CDC stage A3, B3, or C) and were carefully screened for comorbid conditions but were not selected based upon perceived risk for NCI. A slightly different test battery was used with the pre-CART and CART era participants, but the use of normative standards based upon demographically matched HIV-uninfected (HIV-) controls from each era helped assure comparability of impairment classifications. Rates of NCI in this study were much more typical of clinical populations selected only for having strict comorbidity exclusions and were similar for the pre-CART and CART groups ( $41 \%$ vs. $39 \%)$. Interestingly, NCI patterns differed between the two groups, suggesting that patterns of CNS pathology may have changed in the CART era (Joska et al. 2010).

The current study is most similar to that of Cysique et al. (2004) in that we assembled groups of participants who were not selected for being at high risk for NCI from the two treatment eras. The test batteries and methods for classifying NCI also were somewhat different in the two studies, and yet rates of NCI were quite similar for participants with comparable disease stage (all HIVinfected participants in the Cysique et al. study had AIDS): pre-CART rates were $41.1 \%$ for the Cysique et al. study versus $37.4 \%$ in the current study, and CART era rates were $38.8 \%$ in the Cysique et al. study versus $38.5 \%$ in this study.

The current study extended the findings of prior NCI comparisons in the two HIV treatment eras by providing data from large, well-characterized samples of HIV controls and HIV + participants across the full spectrum
Fig. 2 NP Domain impairment in pre-CART and CART era HIV+ samples with NCI. SIP speed of information processing, Learn learning efficiency, Recall delayed recall, Attn/WM attention/working memory, Exec executive function; $* p<0.05$; $* * p<0.01 ; * * * p<0.001$

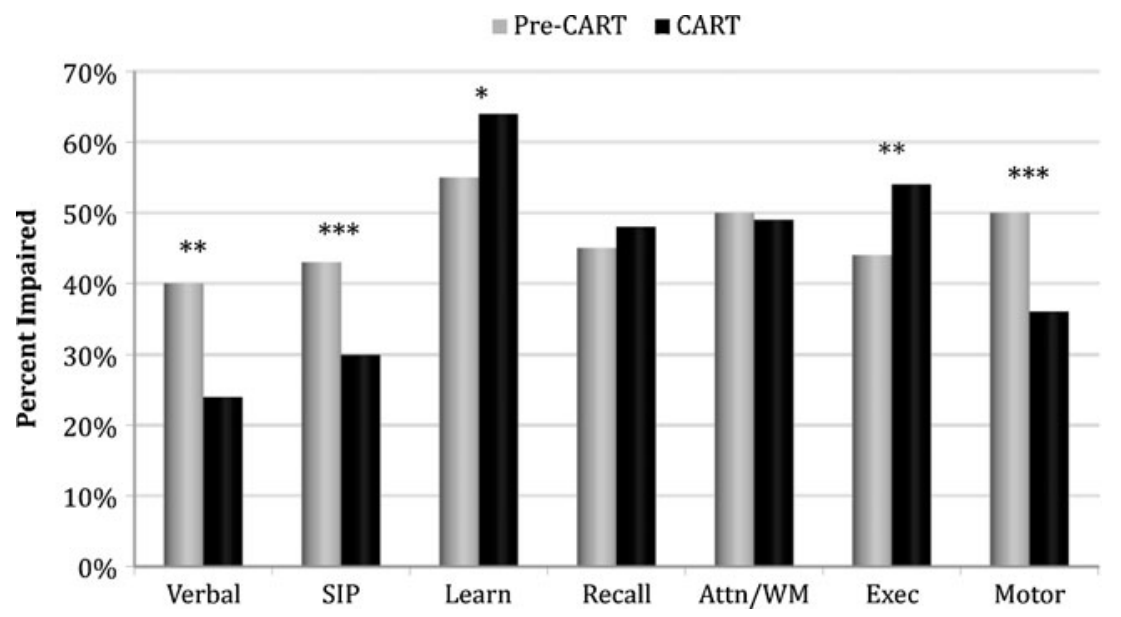


of HIV disease. We found that CART era participants with medically asymptomatic or minimally symptomatic disease histories actually had a higher NCI rate than their pre-CART counterparts. This was true despite the facts that more CART-era participants who had remained medically asymptomatic were receiving antiretroviral therapy and that, as a group, they had comparably mild degrees of current immunosuppression and were much more likely to have viral suppression in both plasma and CSF. Although they had significantly higher rates of lifetime substance use disorders and longer durations of infection, treatment era differences in these factors were present at all disease stages and were unrelated to NCI in the CART era cohort. We suggest that the most important difference between CDC-A participants in the two eras that may have contributed to their different NCI rates is that participants in the CART era had much lower nadir CD4 cell counts. The era difference in nadir degree of immunosuppression (nadir CD4) is much larger for CDC-A than for the other disease stages, and low nadir CD4 was a robust predictor of NCI in both treatment eras. In fact, our finding regarding the importance of a low nadir CD4 as a risk for HAND has been reported now in multiple large studies in the USA ( Heaton et al. 2009; Robertson et al. 2007) and other countries (Cysique et al. 2009; Munoz-Moreno et al. 2008; Tozzi et al. 2005).

The fact that NCI was associated with being on ART only in the CART era raises the question of whether some of the newer ARV medications may have toxic effects on the CNS. Although this possibility cannot be ruled out and deserves further study, it cannot be adequately evaluated in a crosssectional study because clinical decisions about when to initiate treatment are based upon indicators of disease severity (nadir CD4 and medical symptoms) that themselves are risks for NCI. In any event, the increased rate of NCI among CART era (vs. Pre-CART) participants who were medically asymptomatic (CDC stage A) cannot be explained by neurotoxic effects of ARVs because NCI was not significantly related to treatment status in these individuals.

There were intriguing shifts between pre-CART and CART eras when we focus on more severe NCI (i.e., those meeting Frascati neurocognitive criteria for HAD; Antinori et al. 2007). Whereas in CDC stage $\mathrm{C}$ disease, the rate of HAD level NCI in the CART era was less than half that of the pre-CART era $(6.9 \%$ vs. $16.7 \%, p<0.01$; Table 1 ), the rate of more severe NCI was actually higher in the CART era at CDC stage A $(7.1 \%$ versus $3.6 \%, p<0.05$ ). It is possible that the fact that CART era CDC stage As had a greater likelihood of experiencing prior $\mathrm{CD} 4<$ 200 , plus their longer survival with chronic immune stimulation might be playing a role in increasing their risk for evolving brain (neurological) complications.

Prior studies in both pre-CART and CART eras have demonstrated associations between NCI and HIV RNA levels in the periphery (Childs et al. 1999; Ferrando et al. 1998; Nath et al. 2008) as well as in the CSF (Brew et al. 1997; Cysique et al. 2009; Ellis et al 1997b; Letendre et al. 2004; McArthur et al. 1997). However, recent reports indicate that viral suppression on treatment is not sufficient to avoid development or persistence of NCI (Marra et al. 2009; Simioni et al. 2010). Prior analyses of data from the current CNS HIV Antiretroviral Therapy Effects Research (CHARTER) cohort (from which our CART era cases were drawn) suggested that the best neurocognitive outcomes may be associated with a combination of successful viral response to CART and absence of historical severe immunosuppression (nadir CD4<200; Heaton et al. 2010). In the present study, treated subgroups from neither era demonstrated an association between NCI and viral suppression in plasma; however, non-detectable virus in CSF was a positive indicator of normal cognitive function in the pre-CART subgroup only. Our findings support other observations that certain biomarkers of CNS disease that seemed promising in the pre-CART era (e.g., CSF viral load) are not so useful in the CART era (Cysique et al. 2005).

Both our study and the Cysique 2004 study found treatment era differences in pattern of NCI that might be consistent with a shift toward more cortical (vs. subcortical and white matter) involvement in the CART era. A problem with interpreting these differences as reflecting a shift toward greater cortical pathology is that the test battery is not specifically designed to detect such distinctions (e.g., more coverage of language and visuospatial functions would be desirable). Whether such differences in pattern of NCI are truly related to differences in type or distribution of HIV-related brain injury will require correlative work with studies that also employ neuroimaging or postmortem neuropathological analyses.

The limitations of this study include the fact that we cannot rule out cohort differences in this study that are unrelated to HIV or its treatment, especially given the demographic and HIV risk background differences in these samples, which mirror differences in the US epidemic over time (Centers for Disease Control and Prevention 1992, 1994, 1996, 2000, 2004, 2008). However, we attempted to adjust for demographic effects on neurocognitive test performances by using the same age-, education-, gender-, and ethnicity-corrected normative standards. Also, other than a trivial age difference between impaired and unimpaired participants (statistically significant only in pre-CART), none of these demographic variables related to NCI. Similarly, none of the lifetime or current psychiatric disorders assessed here (MDD and alcohol or other substance use disorders) were consistently related to $\mathrm{NCI}$ across treatment eras nor was the risk factor of "any IDU history" (per selection criteria, this was not current and not complicated by associated significant overdoses or traumatic brain injuries). Although HIV infection risk backgrounds also 
differed between treatment era cohorts, these were unrelated to NCI in the pre-CART era; in the CART era cohort, having "only heterosexual contact" was the sole reported HIV risk factor associated with a higher rate of NCI.

NCI was classified and characterized in our two treatment era cohorts using a largely overlapping test battery (11 of 14 individual test measures were the same) covering the same seven ability constructs and using the same standardized methods consistent with recently published guidelines for diagnosing HAND (Antinori et al. 2007). However, three of the individual test measures did differ and helped to measure attention/working memory, processing speed, and executive functioning in somewhat different ways. On the other hand, each of these ability domains had at least one common test measure across eras. To keep the assessments as comprehensive as possible, we elected to include the three substitute tests in the main analyses reported here; however, when we excluded these measures, rates of NCI did not change significantly across HIV serostatus and disease stage subgroups.

HIV viral loads in plasma and CSF were neither available nor standard of care throughout much of the preCART era and were not assayed in our research program until the later part of that era. Also, the limit of detectability was higher in these earlier assays (400 vs. 50 copies per milliliter in the CART era studies). As a consequence, we had very limited viremia and CSF viral load data for the pre-CART HIV + cohort, and an "undetectable" finding did not necessarily mean the same thing across treatment eras. Nevertheless, the availability of these determinations for pre-CART participants was linked only to timing of the assessments (no other selection bias). Also, to permit at least preliminary treatment era comparisons involving viral suppression on treatment, we retrieved and analyzed all available stored samples on pre-CART participants to obtain total sample sizes of 110 (55 each for plasma and CSF) with NCI and 176 ( 85 for plasma and 91 for CSF) without NCI. Impairment rates were similar for the preCART participants with and without viral load determinations, suggesting that the subgroups with viral load data were fairly representative. The main finding of a pre-CART association between NCI and failure of CSF viral suppression on treatment was statistically significant despite the reduced sample size (total $N=138$ ) for this analysis.

In sum, we found high rates of NCI in large HIV + cohorts tested in the pre-CART and CART eras. The only significant treatment era difference was in the medically asymptomatic stage, in which a higher rate and severity of impairment was seen in the CART era participants. The latter CART era subgroup also had the largest discrepancy (relative to their pre-CART counterparts) in nadir CD4 cell counts. Due to the major degree of immune reconstitution and viral suppression seen with the CART-treated partic- ipants, current $\mathrm{CD} 4 \mathrm{~s}$ and viral loads were no longer significant indicators of risk for NCI. The fact that low nadir CD4 was a similarly robust predictor of impairment in both eras is consistent with the view that early severe immunosuppression may initiate at least partially irreversible changes in the CNS and that earlier treatment aimed at protecting patients from these processes may improve CNS outcomes (Heaton et al. 2010). In view of the persisting high rates of NCI in the CART era, especially in HIV + individuals with a history of low nadir CD4s, clinical trials are needed to assess the value of initiating treatment in neurocognitively normal persons before they become markedly immunosuppressed. This type of longitudinal study, in which treatment is not linked to evidence of advancing disease, also may provide the most interpretable information about potentially neurotoxic effects of ARVs.

\section{Materials and methods}

Subjects

Pre-CART subjects were selected from the original cohort of the HNRC at the University of California San Diego. This subgroup consisted of 179 HIV-uninfected (HIV-) and 678 HIV-infected $(\mathrm{HIV}+)$ participants who had been enrolled into the HNRC study between December 1988 and December 1995. Exclusionary criteria for these subjects included any history of neurologic disorders and other conditions (e.g., psychiatric disorder with psychotic features, medications with CNS effects) known to affect neurocognitive performance

HIV seronegative cases for CART era comparisons $(n=$ 94) were selected from a larger group of HIV - subjects enrolled in the NIDA Program Project "Effects of Methamphetamine and HIV" at the HNRC. Subjects were enrolled between May 1999 and May 2004 and had the same exclusion criteria as the pre-CART cases.

The HIV + CART subjects $(n=843)$ in this study were drawn from the six participating university centers of the CHARTER study: Johns Hopkins University (Baltimore, MD, $n=99$ ), Mt. Sinai School of Medicine (New York, NY, $n=152$ ), University of California San Diego (San Diego, CA, $n=179$ ), University of Texas Medical Branch (Galveston, TX, $n=142$ ), University of Washington (Seattle, WA, $n=137$ ), and Washington University (St. Louis, MO, $n=134$ ). Subject recruitment began in September 2003 and ended in August 2007.

While there were no formal exclusion criteria for participation in the CHARTER study, we utilized the online supplement to the Antinori et al. (2007) report which provided detailed guidelines for classifying the most commonly encountered comorbid conditions with respect to whether they should be considered incidental, contributing, or confounding. The comorbid conditions specifically 
addressed in the guidelines include developmental disabilities, alcohol and other substance use disorders, traumatic brain injuries and other non-HIV-related neurologic conditions, systemic diseases including co-infection with hepatitis $\mathrm{C}$ virus, and HIV-related opportunistic CNS disease. Although it was recognized that it would be impossible to specify how to rate the full range of potential comorbid conditions and their combinations, the guidelines for the conditions just mentioned exemplified the following basic concepts: (1) incidental conditions are those that may affect neurocognitive performance to a minor degree but would be unlikely (by themselves) to cause an individual to be classified as significantly "impaired"; (2) contributing conditions could cause at least mild neurocognitive impairment, but the severity, nature, and/or timing of the impairment and associated disability make it likely that the currently observed impairment and functional decline also represent significant effects of HIV; and (3) confounding conditions are those that could fully explain significant neuropsychological impairment and currently observed problems with everyday functioning; HIV effects cannot be reliably inferred in these cases. For the purposes of this study, only those CHARTER participants deemed to have incidental comorbidity $(n=843)$ were used for the CART era HIV + cases.

\section{Procedures}

\section{Standard protocol approvals, registrations, and patient consents}

These procedures were approved by the Human Subjects Protection Committees of each participating institution. Written informed consent was obtained from all study participants.

\section{Neuromedical examination}

Neuromedical examination procedures included medical history, structured neurological and medical examination, as well as collection of blood and urine samples. These procedures were performed by physicians, nurse practitioners, or trained nurses and research associates. The staff performing neuromedical and NP assessments was certified by the coordinating center (University of California, San Diego).

\section{Laboratory assessment}

HIV infection was diagnosed by enzyme-linked immunosorbent assay with Western blot confirmation. Routine clinical chemistry panels, complete blood counts, rapid plasma reagin, hepatitis $\mathrm{C}$ virus antibody, and CD4+ T cells (flow cytometry) were performed at each site's Clinical Laboratory Improvement Amendments (CLIA)-certified, or CLIA equivalent, medical center laboratory. HIV RNA levels were measured centrally in plasma and CSF by reverse transcriptasepolymerase chain reaction (Roche Amplicor, v. 1.5, lower limit of quantitation 50 copies per milliliter).

\section{Neurobehavioral examination}

All the participants completed a comprehensive neurocognitive test battery, covering seven cognitive domains known to be commonly affected by HIV-associated CNS dysfunction (administration time $=2-2.5 \mathrm{~h}$; see Table 4 for listing of

Table 4 Tests and Sources of Normative Data for the Neuropsychological Battery

\begin{tabular}{|c|c|}
\hline Cognitive Domain and Test & Normative Data \\
\hline \multicolumn{2}{|l|}{ Speed of Information Processing } \\
\hline Digit Vigilance Time ${ }^{a}$ & $\begin{array}{l}\text { Heaton, Miller, Taylor, \& Grant } \\
\text { (Heaton et al, 2004a) }\end{array}$ \\
\hline WAIS-III Digit Symbol & $\begin{array}{l}\text { Heaton, Taylor, \& Manly (Heaton } \\
\text { et al, 2002) }\end{array}$ \\
\hline WAIS-III Symbol Search ${ }^{\mathrm{b}}$ & $\begin{array}{l}\text { Heaton, Taylor, \& Manly (Heaton } \\
\text { et al, 2002) }\end{array}$ \\
\hline Trail Making Test, Part A & $\begin{array}{l}\text { Heaton, Miller, Taylor, \& Grant } \\
\text { (Heaton et al, 2004a) }\end{array}$ \\
\hline \multicolumn{2}{|l|}{ Learning and Memory (2 domains) } \\
\hline Story Memory Test & $\begin{array}{l}\text { Heaton, Miller, Taylor, \& Grant } \\
\text { (Heaton et al, 2004a) }\end{array}$ \\
\hline Figure Memory Test & $\begin{array}{l}\text { Heaton, Miller, Taylor, \& Grant } \\
\text { (Heaton et al, 2004a) }\end{array}$ \\
\hline \multicolumn{2}{|l|}{ Abstraction/Executive Functioning } \\
\hline Halstead Category Test ${ }^{\mathrm{a}}$ & $\begin{array}{l}\text { Heaton, Miller, Taylor, \& Grant } \\
\text { (Heaton et al, 2004a) }\end{array}$ \\
\hline $\begin{array}{l}\text { Wisconsin Card Sorting Test } \\
(64-\text { item })^{\mathrm{b}}\end{array}$ & $\begin{array}{c}\text { Kongs, Thompson, Iverson, \& } \\
\text { Heaton (Kongs et al, 2000) }\end{array}$ \\
\hline Trail Making Test, Part B & $\begin{array}{l}\text { Heaton, Miller, Taylor, \& Grant } \\
\text { (Heaton et al, 2004a) }\end{array}$ \\
\hline \multicolumn{2}{|l|}{ Verbal Fluency } \\
\hline $\begin{array}{l}\text { Controlled Oral Word Association } \\
\text { Test }\end{array}$ & $\begin{array}{l}\text { Heaton, Miller, Taylor, \& Grant } \\
\text { (Heaton et al, 2004a); }\end{array}$ \\
\hline $\begin{array}{l}\text { (Letters F-A-S/P-M-R for Spanish } \\
\text { speaking Bilinguals) }\end{array}$ & $\begin{array}{l}\text { Artiola et al. (Artiola i Fortuny } \\
\text { et al, 1999) }\end{array}$ \\
\hline Category Fluency (Animals) & $\begin{array}{l}\text { Heaton, Miller, Taylor, \& Grant } \\
\text { (Heaton et al, 2004a) }\end{array}$ \\
\hline \multicolumn{2}{|l|}{ Attention/Working Memory } \\
\hline WAIS-R Digit Span ${ }^{\mathrm{a}}$ & $\begin{array}{l}\text { Heaton, Miller, Taylor, \& Grant } \\
\text { (Heaton et al, 2004a) }\end{array}$ \\
\hline $\begin{array}{l}\text { WAIS-III Letter-Number } \\
\text { Sequencing }^{\mathrm{b}}\end{array}$ & $\begin{array}{l}\text { Heaton, Taylor, \& Manly (Heaton } \\
\text { et al, 2002) }\end{array}$ \\
\hline PASAT ( $1^{\text {st }}$ channel only) & $\begin{array}{l}\text { Heaton, Miller, Taylor, \& Grant } \\
\text { (Heaton et al, 2004a) }\end{array}$ \\
\hline \multicolumn{2}{|l|}{ Motor } \\
\hline $\begin{array}{l}\text { Grooved Pegboard Test (Dominant } \\
\text { \& Non-dominant Hands) }\end{array}$ & $\begin{array}{l}\text { Heaton, Miller, Taylor, \& Grant } \\
\text { (Heaton et al, 2004a) }\end{array}$ \\
\hline
\end{tabular}

${ }^{\mathrm{a}}$ Pre-CART era only; ${ }^{\mathrm{b}}$ CART era only

WAIS-R Wecshler Adult Intelligence Scale-Revised; WAIS III Wecshler Adult Intelligence Scale $3^{\text {rd }}$ Edition; PASAT - Paced Auditory Serial Addition Task 
specific tests). The best available normative standards were used, which correct for effects of age, education, sex, and ethnicity as appropriate. Test scores were automatically converted to demographically corrected standard scores ( $T$ scores) using available computer programs. To classify presence and severity of neurocognitive impairment, we applied a published objective algorithm that has been shown to yield excellent interrater reliability in previous multisite studies (Woods et al. 2004). This algorithm conforms to the Frascati criteria for diagnosing HAND (Antinori et al. 2007), which require presence of the least mild impairment in at least two of the seven ability domains.

Although the neurocognitive test batteries between the HNRC (pre-CART era) and CHARTER (CART era) studies were similar, there were some test substitutions in the neurocognitive test battery for the CART era subjects. The WAIS-III Symbol Search Test was used in place of the time (speed) component of the Digit Vigilance Test; the WAISIII Letter Number Sequencing Test was used in place of the WAIS-R Digit Span Test; and the Wisconsin Card Sorting Test 64 Card Version was used in place of the Halstead Category Test. All test substitutions were determined to be tapping the same cognitive domain as the original test, and secondary analyses were performed to ensure similar patterns of findings with respect to NCI rates in treatment era and CDC stage group comparisons.

\section{Psychiatric examination}

Psychiatric diagnoses were assessed using the Structured Clinical Interview for DSM-IV (SCID; First et al. 1994) for the pre-CART subjects or the computer-assisted Composite International Diagnostic Interview (CIDI) (World Health Organization 1997) for the CART subjects. Both are structured instruments widely used in psychiatric research. The SCID and CIDI classify current (within the last 30 days) and lifetime diagnoses of mood disorders and substance use disorders, as well as other mental disorders. Current mood was assessed with the Beck Depression Inventory (BDI) or the Beck Depression Inventory-II (BDIII; Beck et al. 1961, 1996).

\section{Functional impairment in everyday life}

Reports of cognitive difficulties in everyday life were assessed using the Patient's Assessment of Own Functioning Inventory (PAOFI; Chelune et al. 1986). The PAOFI includes 33 items on which participants rate themselves as having neurobehavioral difficulties in their everyday lives. Domains of memory, language and communication, sensory-perceptual and motor skills, and higher-level cognitive functions are assessed. A total summed score is derived, with higher scores indicating more difficulty.
Acknowledgments The CNS HIV Antiretroviral Therapy Effects Research (CHARTER) is supported by award N01 MH22005 from the National Institutes of Health.

The CNS HIV Antiretroviral Therapy Effects Research (CHARTER) group is affiliated with the Johns Hopkins University; Mount Sinai School of Medicine; University of California, San Diego; University of Texas, Galveston; University of Washington, Seattle; and Washington University, St. Louis, and is headquartered at the University of California, San Diego, and includes Director: Igor Grant, M.D.; Co-directors: J. Allen McCutchan, M.D., Ronald J. Ellis, M.D., Ph.D., Thomas D. Marcotte, Ph.D.; Center Manager: Donald Franklin, Jr.; Neuromedical Component: Ronald J. Ellis, M.D., Ph.D. (P.I.), J. Allen McCutchan, M.D., Terry Alexander, R.N.; Laboratory, Pharmacology, and Immunology Component: Scott Letendre, M.D. (P.I.), Edmund Capparelli, Pharm.D.; Neurobehavioral Component: Robert K. Heaton, Ph.D. (P.I.), J. Hampton Atkinson, M.D., Steven Paul Woods, Psy.D., Matthew Dawson; Virology Component: Joseph K. Wong, M.D. (P.I.); Imaging Component: Christine Fennema-Notestine, Ph.D. (P.I.), Terry L., Jernigan, Ph.D., Michael J. Taylor, Ph.D., Rebecca Theilmann, Ph.D.; Data Management Unit: Anthony C. Gamst, Ph.D. (P.I.), Clint Cushman,; Statistics Unit: Ian Abramson, Ph.D. (P.I.), Florin Vaida, Ph.D.; Protocol Coordinating Component: Thomas D. Marcotte, Ph.D. (P.I.), Rodney von Jaeger, M.P.H.; Johns Hopkins University Site: Justin McArthur (P.I.), Mary Smith; Mount Sinai School of Medicine Site: Susan Morgello, M.D. (Co-P.I.) and David Simpson, M.D. (Co-P.I.), Letty Mintz, N.P.; University of California, San Diego Site: J. Allen McCutchan, M.D. (P.I.), Will Toperoff, N.P.; University of Washington, Seattle Site: Ann Collier, M.D. (Co-P.I.) and Christina Marra, M.D. (Co-P.I.), Trudy Jones, M.N., A.R.N.P.; University of Texas, Galveston Site: Benjamin Gelman, M.D., Ph.D. (P.I.), Eleanor Head, R.N., B.S.N.; and Washington University, St. Louis Site: David Clifford, M.D. (P.I.), Muhammad Al-Lozi, M.D., Mengesha Teshome, M.D.

The San Diego HIV Neurobehavioral Research Center (HNRC) group is affiliated with the University of California, San Diego; the Naval Hospital, San Diego; and the Veterans Affairs San Diego Healthcare System and includes: Director: Igor Grant, M.D.; CoDirectors: J. Hampton Atkinson, M.D., Ronald J. Ellis, M.D., Ph.D., and J. Allen McCutchan, M.D.; Center Manager: Thomas D. Marcotte, Ph.D.; Jennifer Marquie-Beck, M.P.H.; Melanie Sherman; Neuromedical Component: Ronald J. Ellis, M.D., Ph.D. (P.I.), J. Allen McCutchan, M.D., Scott Letendre, M.D., Edmund Capparelli, Pharm.D., Rachel Schrier, Ph.D., Terry Alexander, R.N., Debra Rosario, M.P.H., Shannon LeBlanc; Neurobehavioral Component: Robert K. Heaton, Ph.D. (P.I.), Steven Paul Woods, Psy.D., Mariana Cherner, Ph.D., David J. Moore, Ph.D., Matthew Dawson; Neuroimaging Component: Terry Jernigan, Ph.D. (P.I.), Christine Fennema-Notestine, Ph.D., Sarah L. Archibald, M.A., John Hesselink, M.D., Jacopo Annese, Ph.D., Michael J. Taylor, Ph.D.; Neurobiology Component: Eliezer Masliah, M.D. (P.I.), Cristian Achim, M.D., Ph.D., Ian Everall, FRCPsych., FRCPath., Ph.D. (Consultant); Neurovirology Component: Douglas Richman, M.D. (P.I.), David M. Smith, M.D.; International Component: J. Allen McCutchan, M.D. (P.I.); Developmental Component: Cristian Achim, M.D., Ph.D. (P.I.), Stuart Lipton, M.D., Ph.D.; Participant Accrual and Retention Unit: J. Hampton Atkinson, M.D. (P.I.), Rodney von Jaeger, M.P.H.; Data Management Unit: Anthony C. Gamst, Ph.D. (P.I.), Clint Cushman (Data Systems Manager); Statistics Unit: Ian Abramson, Ph.D. (P.I.), Florin Vaida, Ph.D., Reena Deutsch, Ph.D., Anya Umlauf, M.S., Tanya Wolfson, M.A.

The views expressed in this article are those of the authors and do not reflect the official policy or position of the Department of the Navy, Department of Defense, or the US Government. 
Open Access This article is distributed under the terms of the Creative Commons Attribution Noncommercial License which permits any noncommercial use, distribution, and reproduction in any medium, provided the original author(s) and source are credited.

\section{References}

American Academy of Neurology AIDS Task Force (1991) Nomenclature and research case definitions for neurological manifestations of human immunodeficiency virus type-1 (HIV-1) infection. American Academy of Neurology, St. Paul

Antinori A, Arendt G, Becker JT, Brew BJ, Byrd DA, Cherner M, Clifford DB, Cinque P, Epstein LG, Goodkin K, Gisslen M, Grant I, Heaton RK, Joseph J, Marder K, Marra CM, McArthur JC, Nunn M, Price RW, Pulliam L, Robertson KR, Sacktor N, Valcour V, Wojna VE (2007) Updated research nosology for HIV-associated neurocognitive disorders. Neurology 69:1789-1799

Artiola i Fortuny L, Hermosilla Romo D, Heaton RK, Pardee RE III (1999) Manual de normas y procedimientos para la bateiria neuropsicologica en Espanol. m Press, Tucson

Beck AT, Brown GK, Steer RA (1996) Beck depression inventory, 2nd edition manual. The Psychological Corporation, San Antonio

Beck AT, Ward CH, Mendelson M, Mock J, Erbaugh J (1961) An inventory for measuring depression. Arch Gen Psychiatry 4:561-571

Brew BJ, Pemberton L, Cunningham P, Law MG (1997) Levels of human immunodeficiency virus type 1 RNA in cerebrospinal fluid correlate with AIDS dementia stage. J Infect Dis 175:963-966

Centers for Disease Control and Prevention (2008). Revised surveillance case definitions for HIV infection among adults, adolescents, and children aged $<18$ months and for HIV infection and AIDS among children aged 18 months to $<13$ years. Morbidity and Mortality Weekly Reports 57:1-8

Centers for Disease Control and Prevention (1992) HIV surveillance report, 1992. Centers for Disease Control and Prevention, Atlanta, pp 1-23

Centers for Disease Control and Prevention (1994) HIV surveillance report, 2004, vol 6. Centers for Disease Control and Prevention, Atlanta

Centers for Disease Control and Prevention (1996) HIV surveillance report, 1996, vol. 8. Centers for Disease Control and Prevention, Atlanta

Centers for Disease Control and Prevention (2000) HIV surveillance report, 2000, vol 12. Centers for Disease Control and Prevention, Atlanta

Centers for Disease Control and Prevention (2004) HIV surveillance report, 2004, vol 16. Centers for Disease Control and Prevention, Atlanta

Centers for Disease Control and Prevention (2008) HIV surveillance report, 2008. Centers for Disease Control and Prevention, Atlanta

Chelune GJ, Heaton RK, Lehman RA (1986) Neuropsychological and personality correlates of patients complaints of disability. In: Goldstein G, Tarter RE (eds) Advances in clinical neuropsychology, 3rd edn. Plenum, New York, pp 95-126

Childs EA, Lyles RH, Selnes OA, Chen B, Miller EN, Cohen BA, Becker JT, Mellors J, McArthur JC (1999) Plasma viral load and CD4 lymphocytes predict HIV-associated dementia and sensory neuropathy. Neurology 52:607-613

Cysique LA, Maruff P, Brew BJ (2004) Prevalence and pattern of neuropsychological impairment in human immunodeficiency virusinfected/acquired immunodeficiency syndrome (HIV/AIDS) patients across pre- and post-highly active antiretroviral therapy eras: a combined study of two cohorts. J Neurovirol 10:350-357

Cysique LA, Brew BJ, Halman M, Catalan J, Sacktor N, Price RW, Brown S, Atkinson JH, Clifford DB, Simpson D, Torres G, Hall C, Power C, Marder K, McArthur JC, Symonds W, Romero C (2005) Undetectable cerebrospinal fluid HIV RNA and beta-2 microglobulin do not indicate inactive AIDS dementia complex in highly active antiretroviral therapy-treated patients. J Acquir Immune Defic Syndr 39:426-429

Cysique LA, Vaida F, Letendre S, Gibson S, Cherner M, Woods SP, McCutchan JA, Heaton RK, Ellis RJ (2009) Dynamics of cognitive change in impaired HIV-positive patients initiating antiretroviral therapy. Neurology 73:342-348

Dore GJ, McDonald A, Li Y, Kaldor JM, Brew BJ (2003) Marked improvement in survival following AIDS dementia complex in the era of highly active antiretroviral therapy. AIDS 17:15391545

Ellis RJ, Deutsch R, Heaton RK, Marcotte TD, McCutchan JA, Nelson JA, Abramson I, Thal LJ, Atkinson JH, Wallace MR, Grant I (1997a) Neurocognitive impairment is an independent risk factor for death in HIV infection. San Diego Arch Neurol 54:416-424

Ellis RJ, Hsia K, Spector SA, Nelson JA, Heaton RK, Wallace MR, Abramson I, Atkinson JH, Grant I, McCutchan JA (1997b) Cerebrospinal fluid human immunodeficiency virus type 1 RNA levels are elevated in neurocognitively impaired individuals with acquired immunodeficiency syndrome. Ann Neurol 42:679-688

Ferrando S, van Gorp W, McElhiney M, Goggin K, Sewell M, Rabkin J (1998) Highly active antiretroviral treatment in HIV infection: benefits for neuropsychological function. AIDS 12:F65-F70

First MB, Spitzer RL, Gibbion M, Williams JBW (1994) Structured clinical interview for axis I DSM-IV disorders, patient edition (SCID-P). Biometrics Research Department, New York State Psychiatric Institute, New York

Grant I, Atkinson JH, Hesselink JR, Kennedy CJ, Richman DD, Spector SA, McCutchan JA (1987) Evidence for early central nervous system involvement in the acquired immunodeficiency syndrome (AIDS) and other human immunodeficiency virus (HIV) infections. Studies with neuropsychologic testing and magnetic resonance imaging. Ann Intern Med 107:828-836

Heaton RK, Grant I, Butters N, White DA, Kirson D, Atkinson JH, McCutchan JA, Taylor MJ, Kelly MD, Ellis RJ et al (1995) The HNRC 500-neuropsychology of HIV infection at different disease stages. J Int Neuropsychol Soc 1:231-251

Heaton RK, Taylor MJ, Manly JJ (2002) Demographic effects and use of demographically corrected norms with the WAIS-III and WMS-III. In: Tulsky D, Saklofske D, Heaton RK, Chelune G, Ivnik R, Bornstein RA, Prifitera A, Ledbetter M (eds) Clinical interpretation of the WAIS-III and WMS-III. Academic, San Diego

Heaton RK, Miller S, Taylor M, Grant I (2004a) Revised comprehensive norms for an expanded Halstead-Reitan Battery: demographically adjusted neuropsychological norms for African American and Caucasian adults scoring program. Psychological Assessment Resources, Lutz

Heaton RK, Marcotte TD, Mindt MR, Sadek J, Moore DJ, Bentley H, McCutchan JA, Reicks C, Grant I (2004b) The impact of HIVassociated neuropsychological impairment on everyday functioning. J Int Neuropsychol Soc 10:317-331

Heaton RK, Franklin D, Clifford D, Woods SP, Rivera-Mindt M, Vigil O, Taylor MJ, Marcotte T, Atkinson JH, Grant I (2009) HIVassociated neurocognitive impairment $(\mathrm{NCI})$ remains prevalent in the era of combination antiretroviral therapy (CART): the CHARTER Study. In: 16th Conference on Retroviruses and Opportunistic Infections, Montreal, Canada

Heaton RK, Clifford D, Franklin DR, Woods SP, Ake C, Vaida F, Ellis RJ, Letendre SL, Marcotte TD, Atkinson JH, Rivera-Mindt M, Vigil O, Taylor MJ, Collier AC, Marra CM, Gelman BB, McArthur J, Morgello S, Simpson D, McCutchan JA, Abramson I, Gamst A, Fennema-Notestine C, Jernigan T, Wong J, Grant I, for the CHARTER Group (2010). HIV-associated neurocognitive disorders persist in the era of potent antiretroviral therapy: CHARTER Study. Neurology 75:2087-2096 
Hinkin CH, Hardy DJ, Mason KI, Castellon SA, Durvasula RS, Lam MN, Stefaniak M (2004) Medication adherence in HIV-infected adults: effect of patient age, cognitive status, and substance abuse. AIDS 18(Suppl 1):S19-S25

Joska JA, Gouse H, Paul RH, Stein DJ, Flisher AJ (2010) Does highly active antiretroviral therapy improve neurocognitive function? A systematic review. J Neurovirol 16:101-114

Kongs SK, Thompson LL, Iverson GL, Heaton RK (2000) Wisconsin card sorting test-64 card computerized version. Psychological Assessment Resources, Odessa

Letendre SL, McCutchan JA, Childers ME, Woods SP, Lazzaretto D, Heaton RK, Grant I, Ellis RJ (2004) Enhancing antiretroviral therapy for human immunodeficiency virus cognitive disorders. Ann Neurol 56:416-423

Marcotte TD, Heaton RK, Wolfson T, Taylor MJ, Alhassoon O, Arfaa K, Ellis RJ, Grant I (1999) The impact of HIV-related neuropsychological dysfunction on driving behavior. $\mathrm{J}$ Int Neuropsychol Soc 5:579-592

Marcotte TD, Wolfson T, Rosenthal TJ, Heaton RK, Gonzalez R, Ellis RJ, Grant I (2004) A multimodal assessment of driving performance in HIV infection. Neurology 63:1417-1422

Marra CM, Zhao Y, Clifford DB, Letendre S, Evans S, Henry K, Ellis RJ, Rodriguez B, Coombs RW, Schifitto G, McArthur JC, Robertson K (2009) Impact of combination antiretroviral therapy on cerebrospinal fluid HIV RNA and neurocognitive performance. AIDS 23:1359-1366

Mayeux R, Stern Y, Tang MX, Todak G, Marder K, Sano M, Richards M, Stein Z, Ehrhardt AA, Gorman JM (1993) Mortality risks in gay men with human immunodeficiency virus infection and cognitive impairment. Neurology 43:176-182

McArthur JC, Brew BJ (2010) HIV-associated neurocognitive disorders: is there a hidden epidemic? AIDS 24:1367-1370

McArthur JC, Hoover DR, Bacellar H, Miller EN, Cohen BA, Becker JT, Graham NM, McArthur JH, Selnes OA, Jacobson LP et al (1993) Dementia in AIDS patients: incidence and risk factors. Multicenter AIDS Cohort Study. Neurology 43:2245-2252

McArthur JC, McClernon DR, Cronin MF, Nance-Sproson TE, Saah AJ, St Clair M, Lanier ER (1997) Relationship between human immunodeficiency virus-associated dementia and viral load in cerebrospinal fluid and brain. Ann Neurol 42:689-698

Munoz-Moreno JA, Fumaz CR, Ferrer MJ, Prats A, Negredo E, Garolera M, Perez-Alvarez N, Molto J, Gomez G, Clotet B (2008) Nadir CD4 cell count predicts neurocognitive impairment in HIV-infected patients. AIDS Res Hum Retroviruses 24:1301-1307

Nath A, Schiess N, Venkatesan A, Rumbaugh J, Sacktor N, McArthur J (2008) Evolution of HIV dementia with HIV infection. Int Rev Psychiatry 20:25-31

Robertson KR, Smurzynski M, Parsons TD, Wu K, Bosch RJ, Wu J, McArthur JC, Collier AC, Evans SR, Ellis RJ (2007) The prevalence and incidence of neurocognitive impairment in the HAART era. AIDS 21:1915-1921

Sacktor N, McDermott MP, Marder K, Schifitto G, Selnes OA, McArthur JC, Stern Y, Albert S, Palumbo D, Kieburtz K, De Marcaida JA, Cohen B, Epstein L (2002) HIV-associated cognitive impairment before and after the advent of combination therapy. J Neurovirol 8:136-142

Simioni S, Cavassini M, Annoni JM, Rimbault Abraham A, Bourquin I, Schiffer V, Calmy A, Chave JP, Giacobini E, Hirschel B, Du Pasquier RA (2010) Cognitive dysfunction in HIV patients despite long-standing suppression of viremia. AIDS 24:12431250

Tozzi V, Balestra P, Serraino D, Bellagamba R, Corpolongo A, Piselli P, Lorenzini P, Visco-Comandini U, Vlassi C, Quartuccio ME, Giulianelli M, Noto P, Galgani S, Ippolito G, Antinori A, Narciso $P$ (2005) Neurocognitive impairment and survival in a cohort of HIV-infected patients treated with HAART. AIDS Res Hum Retroviruses 21:706-713

Tozzi V, Balestra P, Bellagamba R, Corpolongo A, Salvatori MF, Visco-Comandini U, Vlassi C, Giulianelli M, Galgani S, Antinori A, Narciso P (2007) Persistence of neuropsychologic deficits despite long-term highly active antiretroviral therapy in patients with HIV-related neurocognitive impairment: prevalence and risk factors. J Acquir Immune Defic Syndr 45:174-182

White DA, Heaton RK, Monsch AU (1995) Neuropsychological studies of asymptomatic human immunodeficiency virus-type-1 infected individuals. J Int Neuropsychol Soc 1:304-315

Woods SP, Rippeth JD, Frol AB, Levy JK, Ryan E, Soukup VM, Hinkin CH, Lazzaretto D, Cherner M, Marcotte TD, Gelman BB, Morgello S, Singer EJ, Grant I, Heaton RK (2004) Interrater reliability of clinical ratings and neurocognitive diagnoses in HIV. J Clin Exp Neuropsychol 26:759-778

World Health Organization (1997) Composite international diagnostic interview, version 2.1. WHO, Geneva 